\title{
State of the Art for Metastatic Pancreatic Cancer Treatment: Where Are We Now?*
}

\author{
RITA BALSANO, CHIARA TOMMASI and INGRID GARAJOVA \\ Medical Oncology Unit, University Hospital of Parma, Parma, Italy
}

\begin{abstract}
The prognosis of metastatic pancreatic cancer remains poor despite the recent progress on modern chemotherapeutic regimens, such as FOLFIRINOX, gemcitabine and nab-paclitaxel. A better understanding of the altered signalling pathways and the importance of stroma and the immune environment in pancreatic cancer have led to the development of new clinical trials with promising results. In the present review, a general outline of current first- and second-line therapies is provided. Further, new therapeutic possibilities are reviewed, in particular EGFR and VEGF inhibitors, immunotherapy and PARP inhibitors.
\end{abstract}

Pancreatic ductal adenocarcinoma (PDAC) is associated with poor prognosis, with less than $10 \%$ of patients being alive at 5 years after diagnosis (1-4). Radical surgical resection remains the only possibility of cure for PDAC patients, however, even after radical removal, the probability of relapse is high. Five-year survival rates after surgical resection and adjuvant chemotherapy are approximately $20 \%$, and the average survival of resected patients is between 12 and 20 months (1-4). Around half of the PDAC patients are diagnosed with metastatic disease, mainly due to nonspecific symptoms. These patients should undergo systemic anticancer treatment with palliative intent. Unfortunately, chemotherapy prolongs life by only few months, and PDAC chemoresistance renders most drugs ineffective (1-4). Despite extensive clinical trials, most cytotoxic or targeted

*Presented at the 40th EORTC-PAMM Winter Meeting, February 2019, Verona, Italy.

Correspondence to: Ingrid Garajova, MD, Ph.D., Medical Oncology Unit, University Hospital of Parma, Via Gramsci 14, 43 126 Parma, Italy. Tel: +39 5212660, Fax: +39 521702678, e-mail: ingegarajova@gmail.com

Key Words: Pancreatic cancer, chemotherapy, clinical trials, EGFR, VEGF, review. therapies failed to demonstrate efficacy, and the prognosis of PDAC has only slightly improved over the past 20 years.

In the present review, we will focus on the actual status of metastatic PDAC treatment, in particular first- and second-line treatment possibilities. An overview of the results of clinical trials with new drugs is presented, in particular EGFR and VEGF inhibitors, immunotherapy, and PARP inhibitors.

\section{First-line Therapies}

One of the most important years in the history of metastatic PDAC treatment is 1997, because then, chemotherapy with gemcitabine became the standard of care demonstrating clinical benefit and a moderate improvement in survival in comparison to 5-fluorouracile (5-FU) (5). Another turning point in the treatment of metastatic PDAC arrived with the evidence that the FOLFIRINOX regimen had a better efficacy than gemcitabine alone. The overall survival (OS) was 11.1 months in the FOLFIRINOX group and 6.8 months in the gemcitabine group (hazard ratio (HR) for death, $0.57 ; 95 \%$ confidence interval $(\mathrm{CI})=0.45-0.73 ; p<0.001)(6,7)$. Though, because of the higher rate of toxicity, it remains a treatment indicated for fit patients with good performance status.

There is no direct comparison between the FOLFIRINOX and the gemcitabine-nab-paclitaxel regimen. It has been shown that the last combination is better than gemcitabine alone in metastatic PDAC patients $(7,8)$. The median OS was 8.5 months for the addition of nab-paclitaxel to gemcitabine and 6.7 months in the gemcitabine-alone group. Due to better toxicity profile, the regimen with gemcitabine and nab-paclitaxel is suitable even for patients with low Eastern Cooperative Oncology Group (ECOG) performance status (Table I).

\section{Second-line Therapies}

Second-line therapy of metastatic PDAC has to be considered in the terms of risks and benefits for the patient. The choice of chemotherapy (CT) regimen 
Table I. Summary of first-line therapy regimen in metastatic pancreatic cancer.

\begin{tabular}{lcc}
\hline Option to treat & Performance status & Bilirubin levels \\
\hline Symptomatic treatment & $3 / 4$ & \\
Gemcitabine + Nab-paclitaxel & 2 & And/or $>1.5$ ULN \\
Gemcitabine & 2 & $<1.5$ ULN \\
FOLFIRINOX or Gemcitabine + Nab-paclitaxel & $0 / 1$ & \\
\hline
\end{tabular}

Table II. Summary of clinical trials with EGFR inhibitors in PDAC.

\begin{tabular}{|c|c|c|c|}
\hline Author, Year & Drug tested & Population & Outcome \\
\hline Moore MJ et al. 2005 (12) & $\begin{array}{c}\text { Erlotinib + Gemcitabine } v s \\
\text { Gemcitabine alone }\end{array}$ & Advanced or metastatic PDAC & $\begin{array}{l}\mathrm{HR}=0.82 \\
\mathrm{HR}=0.77\end{array}$ \\
\hline Philip PA et al. 2010 (13) & $\begin{array}{c}\text { Cetuximab + Gemcitabine } v s . \\
\text { Gemcitabine }\end{array}$ & Advanced PDAC & $\begin{array}{l}6.3 \text { months, } \mathrm{HR}=1.06 \\
5.9 \text { months, } \mathrm{HR}=0.23\end{array}$ \\
\hline Ko AH et al. 2016 (15) & Erlotinib + Selumetinib & Advanced PDAC & 7.3 months $(95 \% \mathrm{CI}=5.2-8)$ \\
\hline Harder J et al. 2012 (16) & Capecitabine + Trastuzumab & PDAC with Her2 overexpression & mOS 6.9 months \\
\hline
\end{tabular}

depends on patient's performance status (PS) and on prior treatment (7).

In patients with good PS and a good respond to first line CT, the available options are the "wait \& see" approach or the consideration of surgical resection of the residual disease, if possible. In patients with progression of disease at the first line CT and good PS, the available options include chemoradiation, with capecitabine or 5-FU, or stereotactic body radiation therapy (SBRT) if not previously given and if the primary site is the sole site of progression or CT. The CT regimens depend on prior CT: in patients previously treated with gemcitabine-based therapy, second line CT might include FOLFIRINOX schedule (5-FU/folinic acid/oxaliplatin/irinotecan), FOLFOX schedule (5-FU/ folinic acid/oxaliplatin) or FOLFIRI schedule (5-FU/folinic acid/irinotecan). In patients treated with first-line fluoropyrimidine-based therapy, gemcitabine and albuminbound paclitaxel is the favourite schedule for patients with good PS, even if some regulatory prescription difficulties exist for nab-paclitaxel as second line treatment. In patients with poor PS, single agent CT schedule with gemcitabine, capecitabine or 5-FU are preferred. In patients with $B R C A 1 / 2$ gene mutation, 5-FU can be combined with platinum salts (in particular carboplatinum) as second-line CT. In patients with PS of $3 / 4$, with significant comorbidities and a very short life expectancy, palliative and supportive care and a symptomatic treatment are the only therapies to be considered (9). The use of new drugs, alone or combined with standard CT, should be tested in clinical trials to find new therapeutic strategies for patient with PDAC.
However, even after resection with curative intent, the prognosis of the majority of PDAC patients remains poor. Extensive clinical trials using targeted therapies are needed to find new approaches to improve the response rate of patients with PDAC.

\section{EGFR-inhibitors}

The epidermal growth factor receptor (EGFR) is a transmembrane tyrosine kinase (TK) receptor. After its activation through ligand binding, it can regulate several downstream signaling pathways which regulate cell proliferation, survival, and apoptosis. Activation of EGFR is a significant event in PDAC development. KRAS is an effector molecule responsible for signal transduction from ligand-bound EGFR to the nucleus. In fact, ERK pathway activation promotes tumor transformation after an initial $K-R A S$ mutation (10).

Two classes of EGFR inhibitors have been developed for anticancer treatment: tyrosine-kinase inhibitors (gefitinib, erlotinib) and EGFR monoclonal antibodies (cetuximab, panitumumab). Erlotinib in combination with gemcitabine as first-line treatment for non-resectable PDAC showed small benefit in OS of PDAC patients (11). EGFR tissue status was not associated with patients' outcome (12). Further, the combination of cetuximab and gemcitabine has been investigated in a phase III trial (13). No significant difference was seen between the two arms in median survival (6.3 months for the combination with gemcitabine plus cetuximab arm v 5.9 months for the gemcitabine monotherapy arm; $\mathrm{HR}=1.06, p=0.23$ ) (Table II) (13). 


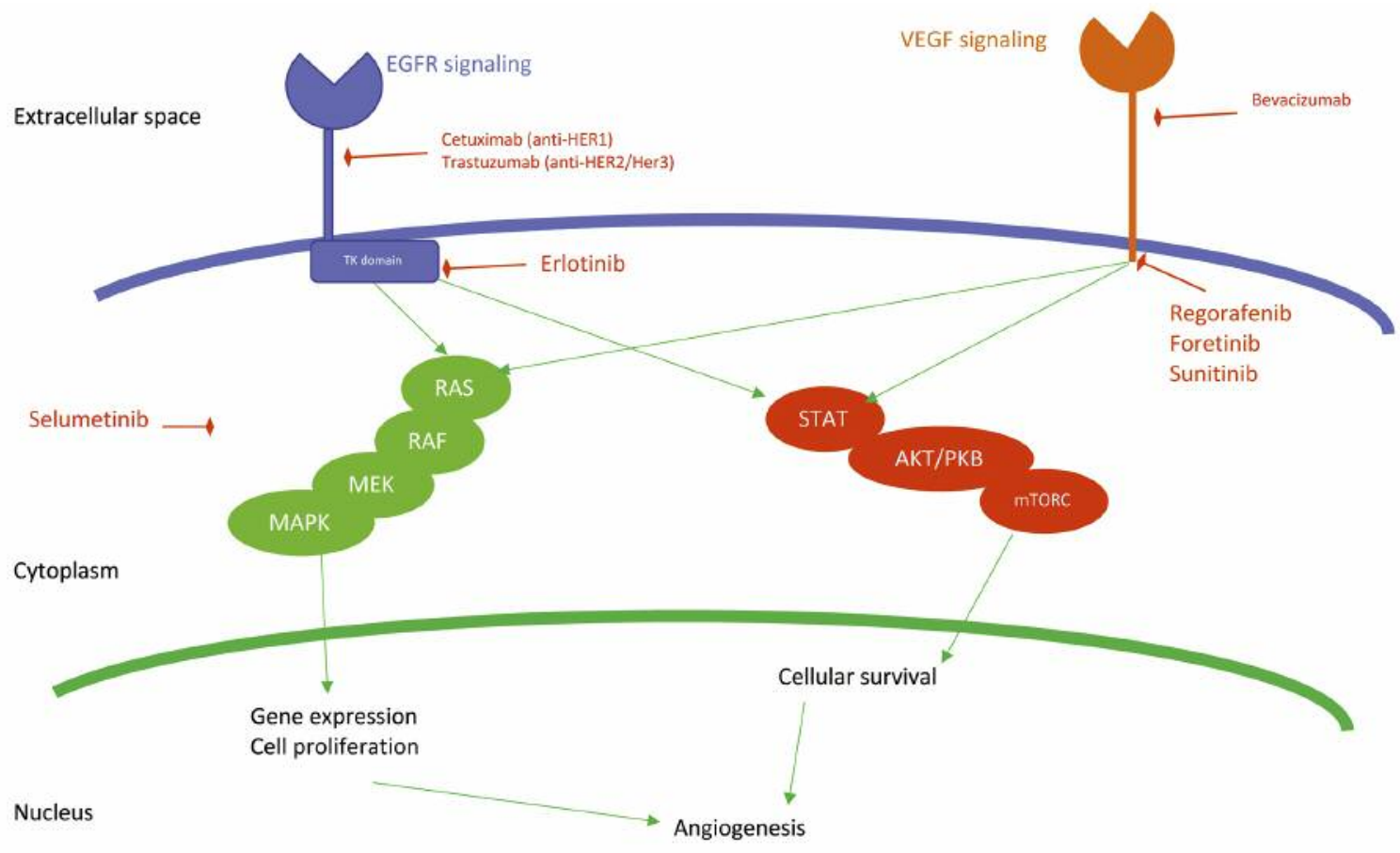

Figure 1. Inhibition of EGFR and VEGF in PDAC. The EGFR is a transmembrane tyrosin kinase receptor. After its activation through ligand binding, it can regulate several downstream signaling pathways which regulate cell proliferation, survival, and apoptosis. Two classes of EGFR inhibitors have been developed for anticancer treatment: tyrosine-kinase inhibitors (e.g. erlotinib) and EGFR monoclonal antibodies (e.g. cetuximab). MEK-inhibitors and anti-HER agents have been studied in monotherapy or combinations, as described in detail in the text. The VEGF is an important factor involved in angiogenesis. Bevacizumab is an anti-human VEGF monoclonal antibody, regorafenib, foretinib and sunitinib are multiple kinase inhibitor suppressing vascular endothelial growth factor receptor.

Over $90 \%$ of PDAC patients harbor somatic mutations in K-RAS. This genetic alteration leads to MAPK effector activation that are responsible for resistance to anti- EGFR therapies (14). To overcome this resistance mechanism, the addition of erlotinib to MEK-inhibitor (selumetinib) has been investigated in a phase II clinical trial (15). Poteet $e t$ al. have investigated a combination of EGFR inhibitors (cetuximab, gefitinib) with trametinib (MEK-inhibitor) and concluded that this combination could present a novel effective treatment for PDAC (16). Moreover, the authors found possible predictors of sensitivity to EGFR-inhibitors (mesothelin and TGF- $\alpha$ ) (17).

HER2 amplification was found in $2-29 \%$ of patients with PDAC (6). The anti-HER2 therapeutic approach has also been investigated in PDAC patients. In a phase II trial, 17 PDAC patients with HER2 overexpression (IHC3+ or IHC2+ with HER2 gene amplification) were treated with capecitabine combined with trastuzumab (18). Unfortunately, this treatment did not prolong survival of patients compared to standard chemotherapy. The role of novel anti-HER agents in PDAC remains to be explored. The possibilities of EGFR pathway inhibition are shown in Figure 1.

\section{VEGF Inhibitors}

It's well known that angiogenesis is a crucial process through which cancer can grow and spread to other organs. Many studies have investigated angiogenesis in order to understand its role as a target in the therapy for cancer. Vascular endothelial growth factor (VEGF) is an important factor involved in angiogenesis and it has been shown that it is overexpressed in over $90 \%$ of patients with PDAC (19). Bevacizumab is an anti-human VEGF monoclonal antibody with an anti-tumor activity. A phase III trial of the Cancer and Leukemia Group B (CALGB 80303) explored the effect of the combination of bevacizumab with gemcitabine versus gemcitabine alone in advanced PDAC and produced disappointing results, because there was not improvement in survival (20). In another phase II trial, Astsaturov et al. investigated the effects of the combination of bevacizumab with docetaxel in patients previously treated for metastatic pancreatic adenocarcinoma, and showed that bevacizumab showed no benefit in gemcitabine-refractory metastatic PDAC (21). Regorafenib, which is an oral multi-kinase inhibitor that has also 
Table III. Summary of clinical trials with VEGF inhibitors in PDAC.

\begin{tabular}{|c|c|c|c|}
\hline Author, Year & Drug tested & Population & Outcome \\
\hline Kindler HL et al. 2010 (6) & $\begin{array}{c}\text { Gemcitabine + Bevacizumab } \\
(\text { compared to Gemcitabine }+ \text { Placebo })\end{array}$ & Advanced pancreatic cancer & $\begin{array}{l}\mathrm{OS}=5.8 \text { months } \\
\mathrm{PFS}=3.8 \text { months }\end{array}$ \\
\hline Astsaturov et al. 2011 (7) & $\begin{array}{l}\text { Bevacizumab alone }(\operatorname{arm} A) \text { or } \\
\text { with Docetaxel }(\operatorname{arm~B})\end{array}$ & $\begin{array}{l}\text { Patients with metastatic adenocarcinoma of } \\
\text { the pancreas who had progressive disease } \\
\text { on a gemcitabine-containing regimen }\end{array}$ & $\begin{array}{c}\text { Arm B: } \\
\text { PFS }=48 \text { days } \\
\text { OS }=125 \text { days }\end{array}$ \\
\hline Sponsor: Stuart Salmon, MD & Regorafenib (NCT02080260) & $\begin{array}{l}\text { Metastatic pancreatic cancer patients } \\
\text { who have progressed after prior } \\
\text { chemotherapy with gemcitabine }\end{array}$ & Ongoing \\
\hline Philip PA et al. 2016 (10) & $\begin{array}{c}\text { Gemcitabine alone or Gemcitabine } \\
\text { plus Cetuximab }\end{array}$ & $\begin{array}{c}\text { Unresectable locally advanced or } \\
\text { metastatic pancreatic adenocarcinoma }\end{array}$ & $\begin{array}{c}\text { PFS: } \\
\text { Gemcitabine alone: } \\
3 \text { months; Gemcitabine } \\
\text { + Cetuximab: } \\
3.4 \text { months }\end{array}$ \\
\hline Rougier P et al. 2013 (11) & $\begin{array}{l}\text { Aflibercept or matching placebo } \\
\text { combined with gemcitabine }\end{array}$ & Metastatic pancreatic cancer & $\begin{array}{l}\text { Gemcitabine plus } \\
\text { Aflibercept arm: } \\
\text { OS=6.5 months } \\
\text { PFS=3.7 months }\end{array}$ \\
\hline
\end{tabular}

antiangiogenic activity, is currently under investigation because of its action as an anti-VEGF. Therefore, in an ongoing phase II trial (NCT02080260), regorafenib is administered in metastatic PDAC patients who progressed after prior chemotherapy with gemcitabine and progressionfree survival (PFS) is evaluated. Regorafenib is being also evaluated in combination with gemcitabine (NCT02383433) in metastatic PDAC in a phase II ongoing trial trying to assess PFS, recurrence rate (RR) and OS. A novel drug combination with anti-angiogenic activity, TL118 is tested in an ongoing phase II trial in combination with gemcitabine to treat metastatic PDAC and efficacy, safety and tolerability is evaluated. The administration of TL-118 seems to have encouraging results in PFS in clinical practice (22). Foretinib is another multiple kinase inhibitor suppressing vascular endothelial growth factor receptor-2 (VEGFR-2) which has demonstrated ability to inhibit tumor growth in vivo (23). Sunitinib is a tyrosine kinase inhibitor which has improved PFS in the maintenance setting in metastatic pancreatic cancer (hazard ratio (HR) 0.51 (95\% confidence interval $(\mathrm{CI})=0.29-0.89)$, $p$-value $<0.01)$. (9) Ziv-aflibercept is a recombinant fusion protein which blocks VEGF-A, VEGF-B and P1GF. A phase III trial showed that the drug didn't improve OS in pancreatic cancer when compared to gemcitabine alone (Table III) (24). The possibilities of VEGF pathway inhibition are shown in Figure 1.

It seems that specific therapy targeting only VEGF will not enter clinical practice. Additional studies are needed to understand the molecular pathways in PDAC. The inhibition of multiple targets could lead to more encouraging results.

\section{Immunotherapy}

Despite therapeutic success of immunotherapy in some advanced solid tumors, similar results have not been obtained with PDAC patients. In fact, PDAC is known to be a poorly antigenic tumor and consequently not immunogenic (25). However, many studies have shown that the human immune system can develop a response to $\operatorname{PDAC}(26,27)$. It is assumed that the tumor environment might have a leading role in escaping immune surveillance (25). On this basis, many ongoing trials evaluate immunotherapy alone or in combination with other agents.

A phase II trial evaluated ipilimumab, a human monoclonal antibody that inhibits CTLA-4 in order to develop a T-cell activation, in patients with advanced PDAC. There was a delayed response only in one patient, suggesting no evident improvement. One of the most recent antibodies is anti-PD-L1. Blocking PD-L1 from its interaction with PD-1 facilitates immune response to tumor. Furthermore, it has been shown that TGF- $\beta$ up-regulates PD-L1 gene transcription (28). An ongoing phase IB/II single-arm study (NCT03451773) evaluates the effect of an investigational drug (M7824) with a dual activity against TGF-beta signaling and PD-L1 inhibition in patients previously treated for PDAC. GVAX is a granulocyte-macrophage colonystimulating factor (GM-CSF) gene-transfected tumor cell vaccine (25). In a phase II trial GVAX was administered in sixty PDAC resected patients in combination with chemoradiation. The median disease-free survival (DFS) was 17.3 months (95\% CI=14.6-22.8), showing no significant difference in OS when compared to the historical controls 
Table IV. Summary of clinical trials with immunotherapy agents in PDAC.

\begin{tabular}{|c|c|c|c|}
\hline Author, Year & Drug tested & Population & Outcome \\
\hline Royal RE et al. 2010 (12) & Ipilimumab & $\begin{array}{c}\text { Locally Advanced or metastatic } \\
\text { pancreas adenocarcinoma }\end{array}$ & $\begin{array}{l}\text { A significant delayed } \\
\text { response in only one patient }\end{array}$ \\
\hline National Cancer Institute & M7824 & $\begin{array}{c}\text { Pancreatic cancer already treated } \\
\text { with standard therapies }\end{array}$ & Ongoing \\
\hline Lutz E et al. 2011 (9) & GVAX whole-cell vaccine & Resected pancreatic cancer & $\mathrm{DFS}=17.3$ months \\
\hline Aglietta et al. 2014 (10) & $\begin{array}{l}\text { Gemcitabine with escalating doses } \\
\text { of CTLA-4 inhibitor (Tramelimumab) }\end{array}$ & Metastatic pancreatic cancer & $\mathrm{OS}=7.4$ months \\
\hline Nywening et al. 2010 (11) & $\begin{array}{l}\text { FOLFIRINOW alone or in } \\
\text { combination with CCR inhibitor }\end{array}$ & $\begin{array}{l}\text { Borderline resectable or locally } \\
\text { advanced biopsy-proven } \\
\text { pancreatic ductal adenocarcinoma }\end{array}$ & $\begin{array}{l}\text { Assessable combination: } \\
\text { achieved OR } 32 / 33 \\
\text { disease control }\end{array}$ \\
\hline
\end{tabular}

Table V. Summary of clinical trials with PARP-inhibitors in PDAC.

\begin{tabular}{|c|c|c|c|}
\hline Author, Year & Drug tested & Population & Outcome \\
\hline Kaufman et al. 2015 (35) & Olaparib & $\begin{array}{c}\text { Pretreated ( }>2 \text { prior line) solid tumors, } \\
\text { BRCA mutated patents }\end{array}$ & $\begin{array}{l}\mathrm{PFS}=4.6 \text { months } \\
\mathrm{mOS}=9.8 \text { months }\end{array}$ \\
\hline Lowery, et al. 2018 (36) & Veliparib & $\begin{array}{c}\text { BRCA/PALB2 mutated } \\
\text { previously treated PDAC }\end{array}$ & $\begin{array}{l}\mathrm{mOS}=3.1 \text { months } \\
\mathrm{PFS}=1.7 \text { months }\end{array}$ \\
\hline Domchek et al. 2014 (37) & Rucaparib & $\begin{array}{l}\text { BRCA mutated locally advanced } \\
\text { or metastatic PDAC }\end{array}$ & ORR $16 \%$ \\
\hline
\end{tabular}

treated with adjuvant chemoradiation therapy alone (29). Many trials investigate the efficacy of antibody with immunogenic activity in combination with standard chemotherapy. A phase Ib trial evaluating the administration of gemcitabine with escalating doses of CTLA-4 inhibitor (Tramelimumab) showed OS 7.4 months (95\%CI=5.8-9.4 months) (30). Another phase I trial compared the effect of a CCR2 inhibitor (PF-04136309), an antagonist of the chemokine receptor to FOLFIRINOX in the first arm, with that of FOLFIRINOX alone in the second arm. The results showed that the combination was safe and tolerable and furthermore, the CCR2 inhibitor was able to reduce tumor associated macrophages (Table IV) (31).

Understanding the complexity of PDAC environment may lead to more effective and more personalized therapy and most of all it could help to overcome the poor immunogenicity of PDAC.

\section{PARP-inhibitors}

The importance of genes implicated in DNA damage response or repair pathways in tumor development has been highlighted by the discovery of an increased susceptibility to breast and ovarian cancer in patients harboring germline mutations in
BRCA1 and BRCA2 genes. The presence of BRCA1 and $B R C A 2$ mutations increase also the risk of PDAC $(32,33)$. In order to maintain genomic integrity, cells deploy several mechanisms that detect and repair DNA lesions. Among them, poly(ADP-ribose) polymerase-1 (PARP1) is a family of enzymes that plays import role in DNA damage repair (32). PARP-inhibitors (PARPi), such as olaparib and niraparib have already been approved and are being used in the treatment of the breast and the ovarian cancer with $B R C A$ mutations. As small percentage of PDAC patients harbors BRCA1/2 mutations, there is a rationale of using PARPi as anticancer agents also in PDAC (11). Kaufman et al. treated patients with different tumor types (including PDAC) associated with germline BRCA1/2 mutations with olaparib. The results were challenging, supporting the hypothesis that targeting this mutation is effective regardless of the organ of origin, including PDAC (34-35). Lowery et al. have evaluated the efficacy of veliparib, another PARPi, in patients with germline $B R C A$ or $P A L B 2$ mutations who were pretreated for PDAC. The mOS was 3.1 months and the PFS pf 1.7 months (36) Moreover, rucaparib has also been investigated in a phase II single-arm study as single-agent in PDAC patients with BRCA mutations (both somatic and germline), as summarized in Table V (37). Other clinical trials are ongoing to evaluate 
the efficacy of PARPi in untreated patients with PDAC. Very recently, results from the phase III POLO trial have been presented at the American Society of Clinical Oncology's (ASCO's) 2019 annual meeting. 154 metastatic PDAC patients with germline BRCA mutations were treated with olaparib after platinum-based chemotherapy. PFS were doubled (3.8 vs. 7.4 months), though data for OS were not available. Moreover, the proportion of PDAC patients who had not progressed after two years was increased from $9.6 \%$ to $22.1 \%$ (38).

\section{Other Approaches}

The most common altered genes and pathways include K-RAS, cell cycle and TGF- $\beta$ pathway. Moreover, even if less common, alterations in DNA repair, WNT signaling, chromatin, RNA processing and Notch signaling have been studied and targeted in several clinical trials. K-RAS mutations are found in $90 \%$ of PDAC, CDKN2A mutations in $63 \%$, SMAD4 in 33\% and TP53 in 26\% (1-4, 7). Most of these mutations or altered signaling pathways have been targeted in clinical trials by stem cell inhibitors, CDK $4 / 6$ inhibitors, insulin-like growth factor inhibitors, tropomyosin receptor kinase inhibitors, and STK11 pathway inhibitors. Moreover, exploring the efficacy of drugs targeting stroma, macrophages or metabolism is an interesting approach for PDAC treatment $(1-4,7)$.

Recently, TGF- $\beta$ inhibitors have been investigated in clinical trials with promising results. The TGF- $\beta$ pathway is altered in $14 \%$ of PDAC patients $(1-4,7)$. Alteration of this pathway results in phosphorylation of SMAD proteins which are often mutated in PDAC and subsequently affects cell differentiation, tumor migration and invasion $(1-4,7)$. Galunisertinib contrasts the three ligands of TGF- $\beta$ and its efficacy has already been investigated as monotherapy or in combination with other agents (gemcitabine, durvalumab). The combination with the immune checkpoint inhibitor PD-L1 seems to be interesting, as it has been shown that TGF- $\beta$ up-regulates PD-L1 gene transcription $(1-4,7)$.

\section{Conclusion}

For over two decades, gemcitabine has been the standard treatment for locally advanced and metastatic PDAC. In 2011, FOLFIRINOX regimen, and in 2013 the combination of gemcitabine with nab-paclitaxel, showed clear superiority to gemcitabine monotherapy. Recently, better understanding of the signalling pathways involved and recognition of the importance of stroma and immune environment in PDAC have led to development of novel drugs that have been tested in clinical trials; some of them have produced disappointing results. New drug combinations may lead to promising results in PDAC treatment.

\section{Conflicts of Interest}

The Authors declare that this paper content has no conflict of interests.

\section{Authors' Contributions}

I.G. designed the review, corrected the chapters and wrote the introductive and conclusion part. R.B. developed in particular the chapter dealing with immunotherapy and VEGF anticancer therapy. C.T. developed the chapters about anti-EGFR therapy and PARPinhibitors.

\section{References}

1 Verdaguer H, Arroyo A and Macarulla T: New horizons in the treatment of metastatic pancreatic cancer: a review of the key biology features and the most recent advances to treat metastatic pancreatic cancer. Targeted Oncol 13(6): 691-704, 2018. PMID: 30470972. DOI: $10.1007 / \mathrm{s} 11523-018-0609-7$

2 Garajová I, Le Large TY, Frampton AE, Rolfo C, Voortman J and Giovannetti E: Molecular mechanisms underlying the role of microRNAs in the chemoresistance of pancreatic cancer. Biomed Res Int 2014: 678401, 2014. PMID: 25250326. DOI: $10.1155 / 2014 / 678401$

3 Neoptolemos JP, Palmer DH, Ghaneh P, Psarelli EE, Valle JW, Halloran CM, Faluyi O, O'Reilly DA, Cunningham D, Wadsley J, Darby S, Meyer T, Gillmore R, Anthoney A, Lind P, Glimelius B, Falk S, Izbicki JR, Middleton GW, Cummins S, Ross PJ, Wasan H, McDonald A, Crosby T, Ma YT, Patel K, Sherriff D, Soomal R, Borg D, Sothi S, Hammel P, Hackert T, Jackson R and Büchler MW; European Study Group for Pancreatic Cancer: Comparison of adjuvant gemcitabine and capecitabine with gemcitabine monotherapy in patients with resected pancreatic cancer (ESPAC-4): a multicenter, open-label, randomized, phase 3 trial. Lancet 389(10073): 1011-1024, 2017. PMID: 28129987. DOI: $10.1016 / \mathrm{S} 0140-6736(16) 32409-6$

4 Garajovà I, Balsano R, Tommasi C and Giovannetti E: Noncoding RNAs emerging as novel biomarkers in pancreatic cancer. Curr Pharm Des 24(39): 4601-4606, 2018. PMID: 30659532. DOI: $10.2174 / 1381612825666190119125804$

5 Burris HA, Moore MJ, Andersen J, Green MR, Rothenberg ML, Modiano MR, Cripps MC, Portenoy RK, Storniolo AM, Tarassoff P, Nelson R, Dorr FA, Stephens CD and Von Hoff DD: Improvements in survival and clinical benefit with gemcitabine as first- line therapy for patients with advanced pancreas cancer: A randomized trial. J Clin Oncol 15(6): 2403-2413, 1997. PMID: 9196156. DOI: 10.1200/JCO.1997.15.6.2403

6 Conroy T, Desseigne F, Ychou M, Bouché O, Guimbaud R, Bécouarm Y, Adenis A, Raoul JL, Gourgou-Bourgade S, de la Fouchardière C, Bennouna J, Bechet JB, Khemissa-Akouz F, Péré-Vergé D, Delbaldo C, Assenat E, Chauffert B, Michel P, Montolo-Grillot C and Ducreux; Groupe Tumeurs Digestives of Unicancer; PRODIGE Intergroup: FOLFIRINOX versus gemcitabine for metastatic pancreatic cancer. N Engl J Med 364(19): 1817-1825, 2011. PMID: 21561347. DOI: 10.1056/NEJ Moa1011923

7 Ducreux M, Cuhna AS, Caramella C,Hollebecque A, Burtin P, Goéré D, Seufferlein T, Haustermans K, Van Laethem JL, 
Conroy T and Arnold D; ESMO Guidelines Committee: Cancer of the pancreas: ESMO Clinical Practice Guidelines for diagnosis, treatment and follow-up. Ann Oncol 26(Suppl): v5668, 2015. PMID: 26314780. DOI: 10.1093/annonc/mdv295

8 Von Hoff DD, Ervin T, Arena FP, Chiorean EG, Infante J, Moore M, Seay T, Tjulandin SA, Ma WW, Saleh MN, Harris M, Reni M, Dowden S, Laheru D, Bahary N, Ramanathan RK, Tabernero J, Hidalgo M, Goldstein D, Van Cutsem E, Wei X, Iglesias J and Renschler MF: Increased survival in pancreatic cancer with nabpaclitaxel plus gemcitabine. N Engl J Med 369(18): 1691-703, 2013. PMID: 24131140. DOI: 10.1056/NEJMoa1304369

9 Pelzer U, Schwaner I, Stieler J, Adler M, Seraphin J, Dörken B, Riess $\mathrm{H}$ and Oettle $\mathrm{H}$ : Best supportive care (BSC) versus oxaliplatin, folinic acid and 5-fluorouracil (OFF) plus BSC in patients for second-line advanced pancreatic cancer: a phase IIIstudy from the German CONKO-study group. Eur J Cancer 47(11): 1676-1681, 2011. PMID: 21565490. DOI: 10.1016/ j.ejca.2011.04.011

10 Yamaoka T, Ohba $\mathrm{M}$ and Ohmori $\mathrm{T}$ : Molecular-targeted therapies for epidermal growth factor receptor and its resistance mechanismse. Int J Mol Sci 18(11), 2017. PMID: 29140271 DOI: $10.3390 / \mathrm{ijms} 18112420$

11 Aprile G, Negri FV, Giuliani F, De Carlo E, Melisi D, Simionato F, Silvestris N, Brunetti O, Leone F, Marino D, Santini D, Dell'Aquila E, Zeppola T, Puzzoni M and Scartozzi M: Secondline chemotherapy for advanced pancreatic cancer: Which is the best option? Crit Rev Oncol Hematol 115: 1-12, 2017. PMID: 28602164. DOI: 10.1016/j.critrevonc.2017.03.025

12 Moore MJ, Goldstein D, Hamm J, Figer A, Hecht JR, Gallinger S, Au HJ, Murawa P, Walde D, Wolff RA, Campos D, Lim R, Ding K, Clark G, Voskoglou-Nomikos T, Ptasynski M and Parulekar W; National Cancer Institute of Canada Clinical Trials Group: Erlotinib plus gemcitabine compared to gemcitabine alone in patients with advanced pancreatic cancer. A phase III trial of the National Cancer Institute of Canada Clinical Trials Group (NCIC-CTG). J Clin Oncol 25(15): 1960-1966, 2007. PMID: 17452677. DOI: 10.1200/JCO.2006.07.9525

13 Philip PA, Benedetti J, Corless CL, Wong R, O'Reilly EM, Flynn PJ, Rowland KM, Atkins JN, Mirtsching BC, Rivkin SE, Khorana AA, Goldman B, Fenoglio-Preiser CM, Abbruzzese JL and Blanke CD: Phase III study comparing gemcitabine plus cetuximab versus gemcitabine in patients with advanced pancreatic adenocarcinoma: Southwest oncology group-directed intergroup trial S0205. J Clin Oncol 28(22): 3605-3610, 2010. PMID: 20606093. DOI:10.1200/JCO.2009.25.7550

14 Lee S, Heinrich EL, Lu J, Lee W, Choi AH, Luu C, Chung V, Faklh $\mathrm{M}$ and Kim J: Epidermal growth factor receptor signaling to the mitogen activated protein kinase pathway bypasses ras in pancreatic cancer cells. Pancreas 45(2): 286-292, 2016. PMID: 26262587. DOI: $10.1097 / M P A .0000000000000379$

15 Ko AH, Bekaii-Saab T, Van Ziffle J, Mirzoeva OM, Joseph NM, Talasaz A, Kuhn P, Tempero MA, Collisson EA, Kelley RK, Venook AP, Dito E, Ong A, Ziyeh S, Courtin R, Linetskaya R, Tahiri S and Korn WM: A multicenter, open-label phase II clinical trial of combined MEK plus EGFR inhibition for chemotherapy-refractory advanced pancreatic adenocarcinoma. Clin Cancer Res 22(1): 61-68, 2016. PMID: 26251290. DOI: 10.1158/1078-0432.CCR-15-0979

16 Poteet E, Liu D, Liang Z, Van Buren G, Chen C and Yao Q: Mesothelin and TGF- $\alpha$ predict pancreatic cancer cell sensitivity to EGFR inhibitors and effective combination treatment with trametinib. PLoS One 14(3): e0213294, 2019. PMID: 30921 351. DOI: 10.1371/journal.pone.0213294

17 Li Q, Zhang L, Li XH, Yan H, Yang L, Li Y, Li T, Wang J and Cao B: The prognostic significance of human epidermal growth factor receptor family protein expression in operable pancreatic cancer. BMC Cancer 16(1): 1-10, 2016. PMID: 27871278. DOI: 10.1186/s12885-016-2889-6

18 Harder J, Ihorst G, Heinemann V, Hofheinz R, Moehler M, Buechler P, Kloeppel G, Rocken C, Bitzer M, Boeck S, Endlicher E, Reinacher-Schick A, Schmoor C and Geissler M: Multicentre phase II trial of trastuzumab and capecitabine in patients with HER2 overexpressing metastatic pancreatic cancer. Br J Cancer 106(6): 1033-1038, 2012. PMID: 22374460. DOI: 10.1038/bjc.2012.18

19 Seo Y, Baba H, Fukuda T, Takashima M and Sugimachi K: High expression of vascular endothelial growth factor is associated with liver metastasis and a poor prognosis for patients with ductal pancreatic adenocarcinoma. Cancer 88(10): 2239-2245, 2000. PMID: 10820344.

20 Kindler HL, Niedzwiecki D, Hollis D, Sutherland S, Schrag D, Hurwitz H, Innocenti F, Mulcahy MF, O’Reilly E, Wozniak TF, Picus J, Bhargava P, Meyer RJ, Schilsky RL and Goldberg RM: Gemcitabine plus bevacizumab compared with gemcitabine plus placebo in patients with advanced pancreatic cancer: Phase III trial of the Cancer and Leukemia Group B (CALGB 80303). J Clin Oncol 28(22): 3617-3622, 2010. PMID: 20606091. DOI: 10.1200/JCO.2010.28.1386

21 Astsaturov IA, Meropol NJ, Alpaugh RK, Burtness BA, Cheng JD, McLaughlin S, Rogatko A, Xu Z, Watson JC, Weiner LM and Cohen SJ: Phase II and coagulation cascade biomarker study of bevacizumab with or without docetaxel in patients with previously treated metastatic pancreatic adenocarcinoma. Am J Clin Oncol Cancer Clin Trials 34(1): 70-75, 2011. PMID: 20458210. DOI: $10.1097 /$ COC.0b013e3181d2734a

22 Breuer S, Maimon O, Appelbaum L, Peretz T and Hubert A: TL118 - Anti-angiogenic treatment in pancreatic cancer: A case report. Med Oncol 30(2): 585, 2013. PMID: 26811110. DOI: 10.1007/s12032-013-0585-9

23 Chen H-M, Tsai C-H and Hung W-C: Foretinib inhibits angiogenesis, lymphangiogenesis and tumor growth of pancreatic cancer in vivo by decreasing VEGFR-2/3 and TIE-2 signaling. Oncotarget 6(17): 14940-52, 2015. PMID: 25909285. DOI: 10.18632 /oncotarget.3613

24 Rougier P, Riess H, Manges R, Karasek P, Humblet Y, Barone C, Santoro A, Assadourian S, Hatteville L and Philip PA: Randomised, placebo-controlled, double-blind, parallel-group phase III study evaluating aflibercept in patients receiving firstline treatment with gemcitabine for metastatic pancreatic cancer. Eur J Cancer 49(12): 2633-2642, 2013. PMID: 23642329. DOI: 10.1016/j.ejca.2013.04.002

25 Torphy RJ, Zhu Y and Schulick RD: Immunotherapy for pancreatic cancer: Barriers and breakthroughs. Ann Gastroenterol Surg 2(4): 274-281, 2018. PMID: 30003190.

26 Fukunaga A, Miyamoto M, Cho Y, Murakami S, Kawarada Y, Oshikiri T, Kato K, Kurokawa T, Suzuoki M, Nakakubo Y, Hiraoka K, Itoh T, Morikawa T, Okushiba S, Kondo S and Katoh $\mathrm{H}$ : $\mathrm{CD}^{+}$tumor-infiltrating lymphocytes together with $\mathrm{CD}^{+}$ tumor-infiltrating lymphocytes and dendritic cells improve the prognosis of patients with pancreatic adenocarcinoma. Pancreas 28(1): e26-31, 2004. PMID: 14707745. 
27 Schmitz-Winnenthal FH, Volk C, Z'raggen K, Galindo L, Nummer D, Ziouta Y, Bucur M, Weitz J, Schirrmacher V, Buchler MW and Beckhove P: High frequencies of functional tumor-reactive $\mathrm{T}$ cells in bone marrow and blood of pancreatic cancer patients. Cancer Res 65(21): 10079-10087, 2005. PMID: 16267034. DOI: 10.1158/0008-5472.CAN-05-1098

28 David JM, Dominguez C, McCampbell KK, Gulley JL, Schlom $J$ and Palena C: A novel bifunctional anti-PD-L1/TGF- $\beta$ Trap fusion protein (M7824) efficiently reverts mesenchymalization of human lung cancer cells. Oncoimmunology 6(10): e1349589, 2017. PMID: 29123964. DOI: 10.1080/2162402X.2017.1349589

29 Lutz E, Yeo CJ, Lillemoe KD, Biedrzycki B, Kobrin B, Herman J, Sugar E, Piantadosi S, Cameron JL, Solt S, Onners B, Tartakovsky I, Choi M, Sharma R, Illei PB, Hruban RH, Abrams RA, Le D, Jaffee E and Laheru D: A lethally irradiated allogeneic granulocyte-macrophage colony stimulating factorsecreting tumor vaccine for pancreatic adenocarcinoma: A phase II trial of safety, efficacy, and immune activation. Ann Surg 253(2): 328-335, 2011. PMID: 21217520. DOI: 10.1097/SLA. 0b013e3181fd271c

30 Aglietta M, Barone C, Sawyer MB, Moore MJ, Miller WH Jr, Bagalà C, Colombi F, Cagnazzo C, Gioeni L, Wang E, Huang $\mathrm{B}$, Fly KD and Leone F: A phase I dose escalation trial of tremelimumab $($ CP-675,206) in combination with gemcitabine in chemotherapy-naive patients with metastatic pancreatic cancer. Ann Oncol 225(9): 1750-1755, 2014. PMID: 24907635. DOI: $10.1093 /$ annonc/mdu205

31 Nywening TM, Wang-Gillam A, Sanford DE, Belt BA, Panni RZ, Cusworth BM, Toriola AT, Neiman RK, Worley LA, Yano M, Fowler KJ, Lockhart AC, Suresh R, Tan BR, Lim KH, Fields RC, Strasberg SM, Hawkins WG, DeNardo DG, Goedegebuure SP and Linehan DC: Targeting tumour-associated macrophages with CCR2 inhibition in combination with FOLFIRINOX in patients with borderline resectable and locally advanced pancreatic cancer: A single-centre, open-label, dose-finding, nonrandomised, phase 1b trial. Lancet Oncol 17(5): 651-662, 2016. PMID: 27055731. DOI: 10.1016/S1470-2045(16)00078-4

32 Xu F, Sun Y, Yang SZ, Zhou T, Jhala N, McDonald J and Chen Y: Cytoplasmic PARP-1 promotes pancreatic cancer tumorigenesis and resistance. Intl J Cancer 145(2): 474-483, 2019. PMID: 30614530. DOI: 10.1002/ijc.32108
33 Faraoni I and Graziani G: Role of BRCA mutations in cancer treatment with poly(ADP-ribose) polymerase (PARP) inhibitors. Cancers (Basel) 10(12): 487, 2018. PMID: 30518089. DOI: 10.3390/cancers 10120487

34 Singh RR, Goldberg J, Varghese AM, Yu KH, Park W and O'Reilly EM: Genomic profiling in pancreatic ductal adenocarcinoma and a pathway towards therapy individualization: A scoping review. Cancer Treat Rev 75: 27-38, 2019. PMID: 30927677. DOI: 10.1016/j.ctrv.2019.03.003

35 Kaufman B, Shapira-Frommer R, Schmutzler RK, Audeh MW, Friedlander M, Balmana J, Mitchell G, Fried G, Stemmer SM, Hubert A, Rosengarten O, Steiner M, Loman N, Bowen K, Fielding A and Domchek SM: Olaparib monotherapy in patients with advanced cancer and a germline BRCA1/2 mutation. J Clin Oncol 33(3): 244-250, 2015. PMID: 25366685. DOI: 10.1200/JCO. 2014.56.2728

36 Lowery MA, Kelsen DP, Capanu M, Smith SC, Lee JW, Stadler ZK, Moore Mj, Kindler HL, Golan T and Segal A, Maynard H, Hollywood E, Moynahan M, Salo-Mullen EE, Do RKG, Chen AP, Yu KH, Tang LH and O'Reilly EM: Phase II trial of veliparib in patients with previously treated BRCA-mutated pancreas ductal adenocarcinoma. Eur J Cancer 89: 19-26, 2018. PMID: 29223478. DOI: 10.1016/j.ejca.2017.11.004

37 Shroff RT, Hendifar A, McWilliams RR, Geva R, Epulbaum R, Rolfe L, Goble S, Lin KK, Biankin AV, Giordano H, Vonderheide $\mathrm{RH}$ and Domchek SM: Rucaparib monotherapy in patients with pancreatic cancer and a known deleterious BRCA mutation. JCO Precis Oncol, 2018. PMID: 30051098. DOI: 10.1200/po.17.00316

38 O'Reilly EM, Lowery MA, Segal MF, Smith SC, Moore MJ, Golan HLK, Segal A, Salo-Mullen EE, Hollywood E, Epstein AS, Capanu M, Moynahan ME, Fusco A, Stadler ZK, Do RKG, Chen AP, Yu KH, Tang LH and Kelsen DP: Phase IB trial of cisplatin $(\mathrm{C})$, gemcitabine $(\mathrm{G})$, and veliparib $(\mathrm{V})$ in patients with known or potential BRCA or PALB2-mutated pancreas adenocarcinoma (PC). J Clin Oncol 32: 4023, 2019. DOI: 10.1200/jco.2014.32.15_suppl.4023

Received May 15, 2019

Revised June 16, 2019

Accepted June 17, 2019 